\title{
Peradaban Islam: Sebuah Konstruk Transformasi Ilmu Pengetahuan
}

\author{
Fajar Syarif ${ }^{1}$ \\ ${ }^{1}$ Institut Ilmu Al-Qur'an (IIQ) JAkarta \\ e-mail: fajarsyarif@gmail.com
}

\begin{abstract}
ABSTRAK. Tulisan ini bertujuan untuk menjawab permasalahan konstruk transformasi ilmu perngetahuan dalam Islam. Melalui pendekatan peradaban Islam yang ada pada tulisan ini, maka permasalahn tersbut dapat dijawab. Tulisan ini diakhir dengan kesimpulan bahwa perubahan sosial dan agama menemukan relevansinya ketika sejarah manusia secara faktual tidak pernah lepas dari sisi kehidupan keagamaannya.
\end{abstract}

\begin{abstract}
This paper aims to address the problem of the construct of the transformation of science in Islam. Through the approach of Islamic civilization in this paper, the problem can be answered. This paper concludes with the conclusion that social and religious change finds relevance when human history is factually never separated from the side of its religious life.
\end{abstract}

Kata kunci: agama, ilmu pengetahuan, masyarakat

\section{PENDAHULUAN}

Masyarakat selalu mengalami perubahan sebagai akibat dari proses pergaulan antarindividu manusia. Realitas ini menarik perhatian para sosiolog dan antropolog untuk melakukan kajian mendalam tentang perubahan sosial. Persoalan penting yang perlu disinggung di sini adalah pendapat mereka tentang perubahan sosial itu sendiri. William F. Ogburn berpendapat bahwa perubahan sosial itu meliputi unsur-unsur kebudayaan, baik bersifat materi maupun immateri. Unsur-unsur materi sangat mempengaruhi unsur immateri. Kingsley Davis berpendapat bahwa perubahan sosial adalah perubahan struktur dan fungsi masyarakat. Sedangkan Mac Iver mendefinisikan perubahan sosial dengan perubahan relasi-relasi sosial atau perubahan keseimbangan hubungan sosial. Dengan pendekatan yang agak berbeda, Samuel Koening mengartikan perubahan sosial sebagai modifikasi yang terjadi dalam pola-pola kehidupan manusia yang disebabkan oleh persoalan internal atau eksternal. ${ }^{1}$

E. B. Tylor mendefinisikan agama sebagai kepercayaan terhadap adanya wujud-wujud spiritual. Radcliffe-Brown, seorang antropolog menjelaskan agama sebagai ekspresi bentuk ketergantungan pada kekuatan di luar diri kita sendiri, yakni kekuatan yang dapat kita katakan sebagai kekuatan spiritual atau kekuatan moral. Sedangkan Yinger, sosiolog kontemporer Amerika mengatakan bahwa "agama merupakan sistem kepercayaan dan peribadatan yang digunakan oleh berbagai bangsa dalam perjuangan mereka mengatasi persoalan-persoalan tertinggi dalam kehidupan manusia. Agama merupakan keengganan untuk menyerah kepada

\footnotetext{
${ }^{1}$ Soerjono Soekanto, Sosiologi Suatu Pengantar (Jakarta: Yayasan Penerbit UI, 1974), hal. 217.
} 
kematian, menyerah dalam menghadapi frustasi dan untuk menumbuhkan rasa permusuhan terhadap penghancuran ikatan-ikatan kemanusiaan. ${ }^{2}$

Emil Durkheim dalam, The Elementary Forms of Religious Life pada 1912, mengatakan bahwa semua agama mempunyai ciri yang sama dengan ditandai oleh dua terma: pertama, profane (konsep duniawi), yaitu segala sesuatu yang oleh "perbedaan" tadi diaktifkan dan tetap dijaga keberadaaannya terhadap yang pertama. Kedua, sacred (konsep suci), yaitu segala sesuatu yang oleh "perbedaan" dilindungi dan diisolasikan. Agama adalah suatu sistem kepercayaan yang distukan oleh praktik-praktik yang bertalian dengan "hal-hal yang suci" (sacred), yakni halhal yang dibolehkan dan dilarang (kepercayaan) dan praktik-praktik (ritus) yang mempersatukan suatu komunitas moral yang tunggal, di mana semuanya terpaut sama lain. ${ }^{3}$ Sacred tidak muncul karena sifat-sifat dari obyek yang sacred itu. Dengan kata lain, sacred dilahirkan dari keadaan kolektif yang bergejolak. Upacara-upacara keagamaan, dengan demikian, memiliki suatu fungsi untuk tetap memproduksi ini dalam masyarakat. Di dalam suatu upacara, individu dibawa ke suatu alam yang baginya nampak bebeda dengan dunia sehari-hari.

Karakteristik agama yang dikemukakan oleh Emile Durkheim tidak lepas dari pandangan Durkheim bahwa agama adalah "fakta sosial" non material menempati posisi yang jauh lebih sentral, karena itu agama memrupakan suatu yang tidak dapat dielakkan dalam kehidupan suatu masyarakat. ${ }^{4}$ Sedangkan masyarakat itu sendiri sebagai sesuatu yang riil, berada terlepas dari individu-individu yang kebetulan termasuk di dalamnya dan bekerja menurut prinsip-prinsipnya sendiri yang khas yang tidak harus mencerminkan maksud-maksud individu yang sadar. Karena agama merupakan fakta sosial maka penjelasannya harus oleh fakta-fakta sosial lainnya. Agama merupakan produk dari suatu masyarakat. Sumber agama adalah masyarakat itu sendiri. Masyarakatlah yang menentukan bahwa sesuatu itu bersifat sakral sedangkan yang lain bersifat profan, khusunya dalam kasus yang disebut totemisme. Masyarakat dan agama (atau lebih umum lagi, kesatuan kolektif) adalah satu dan sama. Agama adalah cara masyarakat memperlihatkan diri sendiri dalam bentuk fakta sosial non material.

Pandangan Durkheim ini menunjukkan sikap dukungannya terhadap definisi-definisi agama sebelumnya dan memiliki kesamaan di dalam mengungkapkan hal-hal yang berkaitan dengan agama itu sendiri serta kekuatannya. Durkheim menegaskan bahwa sacred dan "praktikpraktik ritual" merupakan dua unsur penting suatu agama. Di sini dapat kita memahami bahwa agama bagi Durkheim bukan dilihat dari sisi substansi tetapi bentuk yang melibatkan dua unsur tersebut. Untuk membuktikan bahawa agama adalah fakta sosial. Durkheim menjelaskan bahwa konsep-konsep dan kategorisasi hierarkis atas konsep-konsep itu produk sosial. Totemisme berimplikasi pada pengklasifikasian alam yang bersifat hirarki. Sedangkan ide tentang "klasifikasi yang hirarki" muncul sebagai akibat dari pembagian masyarakat menjadi suku-suku dan kelompok-kelompok analog.

Durkheim juga ingin menegaskan adanya relasi antara agama dengan masyarakat yang terlibat dalam masalah ritual. Ritual terwujud dalam pengumpulan orang saat upacara

\footnotetext{
2 Betty R. Scharf, Sosiologi Agama, terjemah oleh Machnun Husein (Jakarta: Prenada Media, 2004), hal. 34

3 Stephen K Anderson, "Sosiolgi Makro-Sebuah Pendekatan terhadap Realitas Sosial," penerjemah Farid Wajdi dan S. Menno (Jakarta: Rajawali, 1993) hal. 518.

${ }^{4}$ Djuretna A. Imam Mughni, "Moral dan Religi Menurut Emile Durkheim dan Henri Bergson," (Yogyakarta: Kanisius, 1994), hal. 128
} 
keagamaan. Berarti ada kepercayaan atas orde moral di mana solidaritas mekanis itu bergabung. Di sini agama tampak sebagai alat integrasi mayarakat, dan praktek ritual secara terus menerus yang menekankan ketaatan manusia terhadap agama turut serta memainkan fungsi penguatan solidaritas. Kesatuan masyarakat pada masyarakat taradisional itu sangat tergantung kepada conscience collective (hati nurani kolektif), dan agama tampak memainkan peran ini. Masyarakat menjadi "masyarakat" karena fakta bahwa anggotanya taat kepada kepercayaan dan pendapat bersama.

Di sisi lain Max Webber mengenalkan istilah "asketisme dunia batin" (inner worldly ascetism), yaitu pandangan hidup asketik untuk membuktikan pada dirinya sendiri akan pilihannya pada kehidupan abadi. Kedua, "rasionalisai", yaitu penguasaan yang semakin meningkat terhadap realitas secara teoritik dengan sarana konsep-konsep yang semakin tepat dan abstrak. Rasional tidak mesti sama dengan "berdasarkan empirik" atau "ilmiah", sebab efektivitas sarana untuk mendapatkan keselamatan tidak dapat dinilai dengan bukti empirik. Sistem agama rasional (calvinis) dapat memainkan peran sentaral dalam menumbuhkan kapitalisme di barat. Bagi Weber, agama berfungsi memelihara kesatuan sosial. Agama dalam menciptakan sistem makna memiliki otoritas dan legitimasi untuk mengarahkan perilaku sosial dan kontrol sosial.

Dari beberapa perspektif di atas kita dapat melihat secara jernih salah satu kritik atas dogma keagamaan yang dikemukakan oleh Max Weber ${ }^{5}$ tentang konsepsi kegiatan ekonomi sebagai suatu beruf, yaitu konsepsi agama tentang "tugas yang ditentukan oleh Tuhan". Di sini Weber berbeda pendapat dengan Santo Thomas Aquino yang melihat "kerja" dalam perspektif doktrin Katolik sebagai suatu keharusan demi kelanjutan hidup. Weber dengan pendekatan Calvinisme, melihat "kerja" tidak sekedar pemenuhan keperluan tetapi suatu tugas suci keagamaan yang akan menjamin kepastian keselamatan diri. Berarti hal ini suatu pengingkaran terhadap sikap hidup keagamaan yang melarikan diri dari dunia. ${ }^{6}$ Pandangan Weber di atas merupakan pemetaan konsekuensi masyarakat beragama yang memungkinkan mempunyai dua karakter dasar, yaitu dinamis dan stagnan.

Masyarakat protestan ia gambarkan sebagai kelompok yang mempunyai dinamika dan memungkinkan untuk selalu mengalami proses perkembangan dan relevansi. Sedangkan kondisi sebaliknya akan dialami oleh kelompok masyarakat beragama yang stagnan. Agama adalah proses rasionalisasi fenomena. Agama bukanlah epifenomena semata. Agama telah memainkan peran kunci dalam pertumbuhan kapitalisme Barat. Di belahan dunia non Barat, agama hanya memberikan rintangan sementara karena sistem ekonomi bahkan seluruh struktur sosial masyarakat pada akhirnya dan menjadi rasional.

Penulis berpendapat bahwa Weber telah menempatkan kasus yang keliru untuk menguatkan pendapat bahwa pemeluk agama Protestan terdorong untuk memikirkan pekerjaan mereka sehari-hari, dalam pekerjaan apapun, sebagai sarana yang mereka gunakan

\footnotetext{
${ }^{5}$ Max Weber lahir pada 21 April 1864 di Erfert dan dibesarkan di Berlin. Ia menempuh studi bidang Hukum, Sejarah dan Teologi pada Universitas Heidelberg, Strassburg, Berlin dan Gottingen. Pada 1889 ia meraih gelar doktor. Weber kemudian mengajar sambil terlibat di berbagai penelitian hingga pada1893 ia diangkat menjadi Guru Besar Ilmu politik dan ekonomi di Freiburg. Pada 1897 menyusul menjadi guru besar ilmu politik di Heidelberg. Pada 1905 Ia menulis yang kemudian menjadi buku yang populer, The Protestan Ethic and the Spirit of Capitalism. Max Weber meninggal dunia pada 14 Juni 1920.

${ }^{6}$ Max Weber, The Protestan Ethic and the Spirit of Capitalism, diterjemahkan oleh Talcott Parsons (New York: Charles Scribner's Son, 1958), hal.20
} 
untuk mengagungkan Tuhan. Pekerjaan mereka seharusnya dikerjakan dengan sungguhsungguh dan rasa tanggung jawab yang sama sebagaimana pendeta Katolik terdorong untuk melaksanakan "panggilan" khusus mereka. Memang terdapat korelasi antara agama Protestan dan perkembangan kapitalisme. Namun kapitalisme itu bukan akibat adanya agama Protestan. Corak Calvinis dalam agama Protestan adalah ideologi yang digunakan untuk mengesahkan kapitalisme dan memperlemah kekuasaan hukum kanon Katolik. Bahkan di beberapa belahan dunia ditemukan akar Calvinisme namun tidak dibarengi dengan kapitalisme.

\section{PERUBAHAN SOSIAL DALAM ISLAM}

Al-Quran menegaskan bahwa sebagai mahluk sosial, secara individu tidak dapat dipisahkan secara sosial dalam hal cara dan konteks pelaksanaannya. Keterikatan ini bukan hanya dari tinjauan kontrak sosial secara historis yang telah terjadi namun juga dari perspektif ikatan primordial yang telah terjadi antara seluruh manusia yang diciptakan Tuhan, atau dalam bahasa Al-Quran diistilahkan dengan bala syahidna, ya, kami menyaksikan, maksudnya, setiap ruh menyatakan dirinya secara individual dalam hubungannya dengan yang lain dan Tuhan mereka. ${ }^{7}$ Maka dapat dipahami bahwa Islam memberikan keleluasaan manusia untuk melakukan kreasi-kreasi dan inovasi dalam ranah kehidupannya. Ayat-ayat mutasyabihat ${ }^{8}$ (interpretatif) dalam al-Quran juga bukti konkret pesan Islam yang menghormati kemerdekaan berpikir. Ayat-ayat mutasyabihat tentu saja membuka peluang munculnya perbedaan pendapat di kalangan umat Islam. Menurut Muhammad Sahrur ${ }^{9}$ dalam bukunya, al-Kitab wa al-Quran, tantangan umat manusia adalah menyelami ayat-ayat mutasyabihat. Sehingga setiap muslim terdorong untuk mengoptimalkan kemampuan pikirya untuk berijtihad yang secara otomatis kehidupannya menadi dinamis dan terhindar dari stagnasi.Umat Islam memberiikan ruang berpikir yang cukup bagi pemeluknya. Perdebatan teologi yang tergambarkan dalam bab-bab sebelumnya merupakan bukti bahwa dinamika itu telah ada dan berkembang cukup baik. Tema perdebatan yang masih sebatas isu-isu teologi memang bukan pilihan ideal. Namun hal itu cukup relevan mengingat rumusan ideal teologi Islam masih sangat terbatas sehingga membuka peluang setiap orang untuk menawarkan ide-idenya.

Ruang lebar untuk berkreasi yang diberikan Islam diakui pula oleh Weber, meskipun dalam konteks ini ia gagal membuat studi mendalam tentang Islam. Menurutnya, Islam adalah agama dari "para serdadu". Pada zaman permulaan Islam "kelas serdadu" ini tamppak membentuk suatu komunitas agama. Karena itu Islam adalah agama yang didukung oleh kelompok status tertentu. Maka dapat dimengerti jika "perang agama" bagi para serdadu ini adalah untuk mendapatkanharta rampaasan, terutama berupa tanah. Kelas sosial ini berorientasi pada "kepentingan feodal". Sehingga dalam pandangan Weber, perang suci yang dikobarkan Islam bukanlah demi keselamatan jiwa namundemi kekayaan. Dengan

\footnotetext{
${ }^{7}$ Wan Mohd Nor Wan Daud, Filsafat dan Praktik Pendidkan Islam (Bandung: Mizan, 1998), hal. 189.

${ }^{8}$ Ayat-ayat Mutasyabihat adalah ayat-ayat yang makna dan maksudnya tidak cukup jelas dan baru dapat dipahami melalui ta'wil dan kajian mendalam yang otoritasnya berada pada kalangan intelektual Islam (ulama). Bisa jadi hanya Allah yang mengetahui makna dan maksud ayat-ayat tersebut, seperti ayat-ayat mengenai perkara ghaib.

${ }^{9}$ Muhammad Sahrur lahir di Damaskus. Syria pada 1936. Ia menyelesaikan studi tingkat menengah pada 1957, kemudian meneruskan belajar ilmu teknik (handasah) di Moskow dan mendapat gelar Diploma pada 1964. Pada 1969 Ia berhasil meraih gelar Magister, dan gelar Doktor pada 1972 dari Universitas Nasional Irlandia. Selepas studinya, Sahrur mengajar bidang studi Geologi di Universitas Damascus. Sedangkan untuk mengasah pengetahuan dan keagamaannya, Sahrur memperdalam Ilmu Filsafat dan fighullughah.
} 
mengalahkan dunia, para serdadu akan mendpatkan "prestise sosial". Maka Weber berpendapat bahwa terciptanya struktur patrimonial yang berlandaskan atas "karisma" penguasa adalah spesifikasi negara Islam, mengingat perkembangan tradisi serdadu sebagai status sosial yang mempunyaihak-hak istimewa. ${ }^{10}$

Pendapat Weber di atas dalam bahasa yang lebih lugas dapat dikatakan bahwa Islam merupakan agama yang cukup dinamis. Islam mampu berdialog dengan realitas yang mengitatari dirinya. Keterbatasan Weber adalah mengamati Islam dalam perspektif perubahan sosial yang terjadi pada kelompok yang bersinggungan dengan Islam. Sehingga dalam tataran ini Weber masih belum sampai pada pengamatannya tentang Islam itu sendiri sebagai suatu agama besar di dunia. Hal ini sebenarnya sejalan dengan fokus kajian Weber yang mencoba menjauhkan diri dari pengajaran teori yang moralistis yang bertujuan untuk memperbaiki masyarakat. ${ }^{11}$ Taufik Abdullah mempunyai analisa tersendiri tentang pandangan Weber ini. Menurut Taufik, berbagai keberatan dapat diajukan terhadap gambarab Weber tentang Islam mengingat gambaran di atas tidak semata disebabkan oleh ketidaksempatan Weber melakukan studi mendalam tentang Islam, namun juga karena ketidaktepatan landasan konseptual dan skap ilmiah. Weber bukan saja muncul sebagai anak eropa yang kagum atas peradabannya tetapi juga pengikut dari kecenderungan intelektual dari masa awal orientalisme. Pengetahuan Islam seluruhnya tergantung pada tulisan-tulisan para pelopor orientalis yang sebagian besardihinggapi oleh suasana "perang salib", dan terutama yang melihat dengan nista zaman Islam yang ketika itu sedang memudar. ${ }^{12}$ Pandangan Weber tentang tentang Islam dapat dikatakan sebagai fenomena sosial, pertama, pendekatan klasik, yaitu metodologi yang melihat bahwa kedudukan sosiologi agama sangat dekat dengan filsafat dan sejarah. Sosiologi agama merupakan refleksidan analisis sistematis terhadap masyarakat, kebudayaan dan agama sebagai proyek manusia. Kedua, pendekatan positivistik, yaitu sosiologi agama sebagai pengetahuan yang empirik-positivistik dan mensejajarkan masyarakat (dan masyarakat agama) sama dengan banda-benda ilmiah (derivasi lebih lanjut dari konstruksi pemikiran Durkheim dan tokohtokoh positivistik lainnya). Konsekuensinya adalah dalam melakukan analaisa sosial menerapkan metode kuantitatif. Konklusi yang diambil bersifat netral tanpa diwarnai pertimbangan sosiologis atau filosofis, dilepas dari konteks sejarah perkembangan yang dialami masyarakat paa waktu lampau. Hal ini dilakukan untuk mencapai hasil yang seobyektif mungkin. Ketiga, pendekatan konflik, yaitu berpandangan bahwa masyarakat yang baik adalah masyarakat yang hidup dalam situasi konfliktual karena konflik sosial dianggap sebagai kekuatan sosial dari perkembangan masyarakat yang ingin maju kepada tahap yang lebih sempurna. Dari sisi sosiologis, aliran konflik melahirkan sosiologi kritik yang tidak menyetujui aliran kuantitatif dari aliran positivisme karena dianggap sebagai sesuatu yang mengasingkan orang ari masyarakat. Konsekuensi logis dari pemikiran ini adalah bahwa agama dalam realitas harus didudukkan dalam sesuatu yang dinamis, heterogen dan konfliktual. Keempat, pendekatan fungsionalistik, yaitu pandangan bahwa masyarakat merupakan suatu sistem yang utuh dan saling membentuk keseimbangan (equilibrium sosial) dari semua institusi di dalamnya. Dari kerangka berpiktir ini maka agama hanya suatu bentuk tindakan manusia yang dilembagakan berada di antara lembaga-lembaga sosila lainnya. Pendekatan fungsionalistik

10 Reinhard Bendix, Max Weber: An Intellectual Potrait (New York: Double Day, Anchor Book, 1962), hal. 334.

${ }^{11}$ Taufik Abdullah, Tesis Weber dan Islam di Indonesia (Jakarta: LP3ES, 1982), hal. 17

12 Taufik Abdullah, Tesis Weber dan Islam di Indonesia, hal. 23 
memandang agama sebagai salah satu lembaga sosial yang memegang kunci penting menjawab kebutuhan mendasar masyarakat, yaitu kebutuhan manusia yang tidak dapat dipenuhi oleh sesuatu yang bersifat dubiawi tetapi dengan "sesuatu yng berada di luar" dunia empirik. Sosiologi fungsionalis tidak menguti hakikat dari "apa yang ada di luar" tetapi hanya melihat pengaruhnya yang nyata. Artinya, sejauh hakikat itu telah mengambil bentuk yang konkret sebagai salah satu lembaga sosial. Para fungsionalis sanggup menjelaskan bahwa baik masyarakat religius maupun masyarakat profan mengembangkan fungsi manusia. Kedua belah pihak mempunyai kewajiban moral untuk menyadari saling ketergantungannya.

\section{JEJAK ISLAM DALAM LOKALITAS}

Bukti adanya batu nisan raja-raja Aceh yang beragama Islam menunjukkan bahwa Islam telah berkembang di kesultanan Aceh pada abad ke 13M. Berbeda dengan di Aceh, kalngan istana di Jawa justru kesulitan menerima Islam. Karena itu para penyebar agama Islam di Jawa lebih menekankan aktivitas dakwahnya di lingkungan masyarakat pedesaaan, khusunya pesisir pulau jawa. Masyarakat pesisir pun menerima Islam dengan antusias. Kemudian Jawa dibanjiri dengan kitab-kitab agama Islam bebahasa Arab yang selanjutnya berkembang menjadi kelompok-kelompok kajian keagamaan yang lebih dikenal dengan sebutan pondok pesantren. ${ }^{13}$

Pesantern adalah lembaga lokal yang mengajarkan praktik-praktik dan keparcayaan Islam. ${ }^{14}$ Definisi yang lebih spesifik dapat dikatakan bahwa pesantren merupakan lembaga keagamaan yang mendidik manusia agar mampu berpegang teguh kepada Al Quran dan mengikuti sunah Rasulullah saw sehingga menjadi pribadi yang menpunyai komitmen dan konsistensi dalam setiap waktu dan kondisi. Dalam sistem pengajarannya, pesantren merupakan pengembangan sistem halaqah yang di dalamnya para santri harus mondok dan hidup dalam rawiyah (kamar penyepian) syaikhnya (guru tarekat). ${ }^{15}$ Simuh mengakatan bahwa sistem pendidikan pesantren berbeda dengan sistem pendidikan agama modernyang menitikberatkan pada analisa kelemahan dan kekuatan isi ajaran kitab itu untuk menciptakan mujtahid. ${ }^{16}$ Menurut penulis, Simuh tidak sepenuhnya benarkarena pada dasarnya sebagian besar pesantren di Indonesia diperuntukkan bagi para pemula. Sehingga perkembangan komunitas pesantren tidak berorientasi pada pemunculan para mujtahid meskipun dalam konteks tertentu metodologi ijtihad telah berlangsung lama di kalangan pesantren.

Dari pesanteran ini kemudian timbul masyarakat pesantren, yaitu sebuah komunitas manusia yang mempunyai karakter dan tradisi pesantren sebagai akibat interaksi mereka dengan pesantren. Kemunculan masyarakat pesantren memang tidak lepas dari pengaruh pesantren. Sedangkan karakter pesantren pesantren dapat diurai dari figur Kiai sebagai sentral komunitas pesantren. Kiai adalh cendekiawan agama (ulama) yang karena Islam tidak memiliki sistem kependetaan, menjadi pemimpin-pemimpin Islam di Jawa. Kiai tidak memperoleh gelar dari sistem pendidikan formal, tetapi lebih dari itu, gelar itu datang dari masyarakat. ${ }^{17}$

Figur Kiai yang sangat kuat dan penguasaannya terhadap ilmu pengetahuan agama menjadikan pesatren sebagai pusat pendidikan dan dakwah Islam. Pesantren memainkan

\footnotetext{
${ }^{13}$ Simuh, Islam dan Pergumulan Budaya Jawa (Jakarta: Teraju, 2003), hal. 66.

14 Ronald Alan Lukens-Bull, Peacefull Jihad diterjemahkan oleh Abdurrahman Mas'ud dkk dengan Judul Jihad ala Pesantren di Mata Antropolog Amerika (Yogyakarta: Gama Media, 2004), hal.56.

${ }^{15}$ Simuh, Islam dan Pergumulan Budaya Jawa, hal. 76.

${ }^{16}$ Simuh, Islam dan Pergumulan Budaya Jawa, hal. 76.

${ }^{17}$ Ronald Alan Lukens-Bull, Peacefull Jihad, hal. 88
} 
peranan penting dalam penyebaran agama Islam di pedalaman pulau Jawa. Bahkan ada kemungkinan beberapa pesantren mengambil alih pusat-pusat keagamaan pra Islam. Menurut Said Aqil Siradj, pada masa permulaan Islam di Jawa, Kiai mengelola pesantren dengan strategi yang cukup unik, yaitu menghindari secara langsung berinteraksi dengan kantong-kantong kekuatan budaya asing dan di sisi lain memperkuat budaya lokal dengan nilai-nilai Islam. Maka saat itu Kiai lebih suka membangun komunitas pesantren yang eksklusif dan sulit terjangkau oleh hiruk pikuk kehidupan kota. Katanya, "masa penjajahan adalah masa dilematis dunia pessantren. Satu sisi harus berhadapan dengan penjajah yang kuat sedangkan di sisi lain harus menjaga kelangsungan tradisi dan keyakinan masyarakat Islam. Pilihan pertama tentu ideal tapi berisiko musnahnya peradaban muslim Nusantara bahkan umat Islam itu sendiri. Sedangkan pilihan kedua masih menyisakan harapan atas kelangsungan tradisi dan keyakinan tersebut. Langkah kedua ini termasuk tipologi orang kalah. Namun dengan pertimbangan kelangsungan peradaban maka para Kiai lebih suka memilih langkah kedua."

Pilihan perjuangan di pedalaman ini kemudian mengidentikkan pesantren sebagai komunitas Islam pedesaan. Dalam penelitian interaksi Islam dan berbagai budaya lokal tentu terdapat kemungkinan Islam mewarnai, mengubah, mengolah dan memperbarui budaya lokal, tetapi mungkin pula Islam yang justru diwarnai oleh berbagai budaya lokal. Masalahnya di sini, apakah pendukung Islam yang aktif (Kiai) atau malah sebaliknya para pendukung budaya lokal yang tellah memahami Islam menurut kacamata warisan budaya lokal mereka. Pada proses inilah peluang lahirnya budaya Islam pesantren. ${ }^{18}$ Gerakan budaya Kiai akhirnya menyisir dari pedalaman desa menuju pinggiran kota dan bahkan ke jantung kota. Kesultanan Demak adalah wujud kemenanganIslam pesantren menyisir kota. Begitu juga upaya Jaka Tingkir (murid Sunan Kudus) memindahkan kesultanan Demak ke Pajang merupakan wujud kemenangan masyarakat pesantren yang dipimpin Arya Jipang. Perselisihan politik yang dilatarbelakangi oleh perbedaan budaya masyarakat pesantren dan kejawen ini terus berlanjut hingga beralihnya Kesultanan Pajang ke Kesultanan Mataram. Sultan Agung memerintah Mataram (1613-1645) akhirnya berhasil mematahkan perlawanan masyarakat pesantren yang dipimpin oleh Sunan Giri (1635). ${ }^{19}$

Memasuki paruh abad XIX jumlah pesantren bertambah banyak dan itu berarti kantong-kantong benteng terakhir kebudayaan lokal semakin menyebar dan menguat . peningkatan arus perdagangan membuat daerah-daerah terpencil (di mana pesantren itu berada) semakin banyak berhubungan dengan dunia luar: mereka sudah benar-benar menjadi dunia kecil tersendiri yang semakin dipengaruhi oleh timur-tengah. ${ }^{20}$ Pesantren semakin kukuh menancapkan eksistensinya sebagai pusat ilmu pengetahuan Islam tetapi juga sentrum rekonstruksi budaya lokal sekaligus benteng terakhir kebudayaab masyarakat pedesaan yang telah mengalami akulturasi dengan Islam. Klaim historis yang lain tentang peantren kemudian terdefinisikan bahwa identitas pesantren itu murni Indonesia. Klaim ini berkaitan dengan peran-peran orang pesantren, khusunya Kiai dalam lingkup yang lebih luas, termasuk perjuangan melawan penjajah, baik pada masa perang melawan kemerdekaan maupun pasca

\footnotetext{
${ }^{18}$ Simuh, Islam dan Pergumulan Budaya Jawa, hal. 18

${ }^{19}$ H.J. Van Den Berg, Asia dan Dunia Sejak 1500, hal. 233, dikutip Simuh, Islam dan Pergumulan Budaya Jawa, hal. 68.

${ }^{20}$ Andre Feillard, NU vis a vis Negara (Yogyakarta: LkiS, 1999), hal. 3
} 
kemerdekaan. Catatan dan laporan sejarah tentang pesantren adalah bukti tertulis tentang peran yang dimainkan oleh orang-orang pesantren selama perang berlangsung. ${ }^{21}$

Keberadaan pesantren tentunya seiring dengan kedatangan Islam di Nusantara, khusunya di Jawa. Sayangnya hal ini hampir bersamaan dengan masa koloni bangsa Barat. Akibatnya seluruh energi dan perhatian umat Islam hanya diarahkan untuk melawan orangorang Barat tersebut. Karena itu Islam di Indonesia belum sempat menciptakan peradaban. ${ }^{22}$ Problem saat itu adalah persoalan klasik dunia ketiga, seperti kemiskinan, rendahnya kualitas pendidikan, di samping juga masalah imperialisme dan kolonialisme bangsa-bangsa Eropa. Layaknya sebuah negara terbelakang dan terjajah, indonesia juga mengalami keterpurukan di segala bidang. Masyarakakt terpolarisasi menjadi dua kelompok besar; pertama penduduk pribumi, yaitu orang-orang yang beragama Islam, baik berasal dari etnis melayu, jawa maupun cina. Kedua, orang barat atau belanda, yaitu orang-orang kristen. Kedua kelompok ini sering terlibat konflik, terutama pada saat transformasi kebudayaan dan ilmu pengetahuan yang melibatkan keduanya. ${ }^{23}$

Praktis pada masa ini proses akulturasi budaya pada masyarakat Islam pesantren di pedesaan tidak semulus sebelumnya. Bangsa eropa yang diwakili belanda, di samping kompetitor baru di bidang kebudayaan juga agresor eksistensi identitas sebuah bangsa. Dalam konteks menghadapi penjajah, muslim pesantren dipicu oleh sikap belanda yang berusaha untuk tetap menjajah. Implikasinya, mereka tidak mampu memperlakukan agama Islam sama dengan agama mereka. Mereka juga tidak mampu memperlakukan muslim pesantren sama dengan non muslim yang bukan dari barat. Latar belakang ini kemudian menimbulkan diskriminasi dalam kebijaksanaan yang berhubungan dengan agama. ${ }^{24}$ Muslim pesantren pun harus menghadapi beberapa persoalan sekaligus, yaitu kolonial belanda dan kaum adat sekaligus meredakan perpecahan dengan golongan nasionalis sekuler. Golongan bangsawan merupakan saingan bersama kedua golongan ini. Golongan nasionalis melawan bangsawan pribumi atas nama demokrasi dan sosialisme, karena golongan ini dianggap mewakili feodalisme. Menilai golongan ini sebagai penghalang terkuat bagi realisasi kehidupan santri. ${ }^{25}$

Kolonilisme barat yang bercorak intervensionis dan kooptatif pada akhirnya menggerogoti otoritas para penguasa pribumi yang berkolaborasi dengan masyarakat eropa. Kaum petani memandang para penguasa mereka tidak lebih dari sekedar anntek eropa. Ketika para penguasa pribumi kehilangan legitimasinya maka popularitas kepemimpinan muslim di luar pemerintah menjadi meningkat. Para ulama yang terpinggirkan dari lingkaran kekuasaan secara perlahan menggantikan posisi elite pribumi dalam menegakkan otoritas politik terhadap kaum petani. Ketika program kolonial memngalami intensifikasi, jawa diguncang oleh berbagai gerakan protes petani. Mula-mula gerakan tersebut bersifat kedaerahan dan sangat partikularistik, jarang mengusung cita-cita Islam. Namun menjelang akhir abad 19 semuanya menjadi berubah. Lantaran gerakan protes tersebut dan berbagai aktivitas lainnya, kolonialisme bangsa eropa selalu merubah struktur dan perkembangan Islam indonesia. Dalam sejumlah serangan mendadak, bangsa eropa menghancurkan kerajaan Islam. ${ }^{26}$ Islam menjadi insprirasi

\footnotetext{
${ }^{21}$ Ronald Alan Lukens-Bull, Peacefull Jihad, hal. 61.

${ }^{22}$ Ridin Sofwan, dkk., Islamisasi di Jawa (Yogyakarta: Pustaka Pelajar, 2004), hal. 286.

${ }^{23}$ Deliar Noer, Gerakan Modern Islam di Indonesia 1900-1942 (Jakarta: LP3ES, 1996), hal. 8-9.

${ }^{24}$ Aqib Suminto, Politik Islam Hindia Belanda (Jakarta: LP3ES, 1985), hal. 14.

${ }^{25}$ Harry J. Benda, The Crescent and the Rising Sun (The Hague: 1985).

${ }^{26}$ Robert W. Hefner, dalam bukunya yang diedit oleh Mun'im Sirry, Islam Liberalisme Demokrasi (Jakarta: Paramadina, 2002), hal. 373.
} 
utama upaya perlawanan masyarakat terhadap kolonial bangsa eropa. Perlawanan itu muncul ketika muslim pesantren telah berpendapat dan bersepakat bahwa pemerintah kolonial merupakan "pemerintah kafir" yang menjajah agama dan bangsa mereka. Bentuk perlawanan lainnya adalah perlawanan kultural. Pesantren memanfaatkan jaringan kulturalnya untuk membendung arus kebudayaan eropa. Seperti, kaum santri secara aktif dan demonstratif menolak segala hal yang berbau belanda: mengharamkan uang gaji belanda dan segala identitas eropa. ${ }^{27}$ Model perlawanan ini pula yang "dicurigai" sebagai sebab terjadinya gelombang kaum santri menempuh studi ke timur-tengah, khususnya ke al-Haramain. Salah satu pemicu obsesi ke luar negeri di abad XIX adalah keinginan kuat untuk naik haji, terutama bagi mereka yang berasal dari luar jawa. Meskipun sebagian besar orang-orang jawa itu hanya menghabiskan beberapa minggu di Hijaz, mereka banyak melakukan hubungan dengan orang-orang senegrinya yang tinggal setengah menetap di Mekkah. Mereka pun menerima pandangan kota suci yang bersifat internasional dan secara tegas anti penjajahan. ${ }^{28}$

Di antara muslim pesantren yang studi ke Mekkah terdapat Syarif Hidayatullah yang lebih dikenal dengan sebutan Sunan Gunung Jati, lahir di pasai namun tidak diketahui tanggal kelahirannya. Ia meninggalkan Nusantara untuk keperluan studi ke al-Haramain. Sekembalinya ke tanah air ia memimpin pasukan menaklukkan kerajaan Hindu Padjajaran dan mendirikan dua kerajaan Islam, yaitu kerajaan Banten dan Cirebon. Kemudian ia mmembangun kota Jayakarta dan menjadikannya sebagai benteng pertahanan melawan penjajahan Portugis. ${ }^{29}$ Selain Syarif Hidayatullah terdapat nama Khatib Sambas, seorang ulama sufi yang lahir di Sambas, Kalimantan Barat 1803. Ia meninggalkan tanah kelahirannya menuju Mekkah pada 1820. Meskipun ia menetap di Mekkah, Khatib Sambas menjalin komunikasi dengan santri di Nusantara. Syaikh Khatib Sambas wafat di Mekkah pada $1875 .{ }^{30}$ Selain itu ada juga Syaikh Nawawi Banten (w. 1887), Syaikh Mahfudz Termas (w. 1923), KH. Hasyim Asy'ari (w. 1946) ${ }^{31}$ dan KH. Ahmad Dahlan (w. 1923).

\section{DINAMIKA MUSLIM INDONESIA}

Memasuki abad XX, di tengah masyarakat muslim kota muncul gerakan baru yang mengusung paham modernitas, Islam modernis terinspirasi oleh gerakan para reformis Islam timur tengah, seperti Jamaludin al-Afghani (1838-1897), Muhamad Abduh (1849-1905) dan Rasyid Ridha (1865-1935). Inti modernisme Islam adalah keyakinan bahwa peradaban Islam sedang mengalami kemerosotan serius. ${ }^{32}$ Gagasan kaum Islam modernis menyebar dengan cepat dan menimbulkan perdebatan cukup luas di kalangan umat Islam di Indonesia. Usaha reformasi Islam di Indonesia, yang dimulai pada abad XIX bertujuan membawa umat Islam yang tidak sepenuhnya taatdan lebih dekat dengan adat atau dengan aliran kebatinan, untuk melaksanakan ajaran Islam secara "lebih benar". Artinya, sesuai yang diberlakukan di tanah Hijaz. Dinamika Islam di Indonesia bermula dari minangkabau, ketika para intelektual muslim yang belajar di Mekkah dan Kairo kembali ke kampung halaman mereka dan menyebarkan semangat dan gagasan-gagasan reformasi Islam. Di Sumatera, penyebaran semangat dan gagasan itu

\footnotetext{
27 Aqib Suminto, Politik Islam Hindia Belanda, hal. 50.

${ }^{28}$ Anthony Reid, Kekacauan dan Kerusuhan (Leiden-Jakarta: INIS, 2003), hal. 4-5

${ }^{29}$ Alwi Shihab, Islam Sufistik (Bandung: Mizan, 2001), hal. 24.

${ }^{30}$ Edy Kunan Hadi, Syaikh Ahmad Khatib Sambas (The Ford Foundation, 2003), hal. 22-23.

${ }^{31}$ Alwi Shihab, Islam Sufistik, hal. 176.

${ }^{32}$ Greg Fealy, Ijtihad Politik Ulama (Yogyakarta: LKiS, 2003), hal. 26
} 
dilakukan lewat madrasah-madrasah, seperti adabiyah,Surau Jembatan Besi, dan Thawalib. Para reformis Islam di Sumatera Barat menganut puritanisme mirip dengan kaum Wahabi, yang menerapkannya melalui kekerasan hingga menyebabkan terjadinya perang Padri. Mula-mula usaha yang dilakukan oleh guru agama ini mendapatkan dukungan dari sebagian para syaikh sufi, kemudian mereka pun menjadi sasaran kekerasan kaum padri. Perang yang kemudian melibatkan pihak Belanda ini berkobar hampir di seluruh bagian barat pulau sumatera dan menyebabkan kekacauan selama tiga puluh tahun. Peperangan baru berhenti dengan ditaklukannya daerah tersebut oleh kolonial belanda. Sedangkan pulau jawa mengalami arus reformasi pada awal abad XX dengan berdirinya beberapa organisasi keagamaan, seperti Muhammadiyah (1912), al Irsyad al Islamiyah (1915), dan Persis (1923). ${ }^{33}$

Muhammadiyah dideklarasikan pada tanggal 18 Nopember 1912. Gerakan dakwah ini mengusung nilai pembaruan Islam, seperti kembali kepada al Quran dan Sunnah, purifikasi Islam, rasionalitas, termasuk kontekstualisasi ajaran Islam. Pendiri Muhammadiyah adalah KH. Ahmad Dahlan (1863-1923), seorang muslim reformis puritan yang asketis. Sosok KH. Ahmad Dahlan yang modernis sebenarnya mempunyai latar belakang tradisionalis. Ia nyaris tidak berbeda dengan prototipe para Kiai di pedesaan yang secara rutin memberikan ceramah keagamaan di forum-forum pengajian, tidak terkecuali menjadi khatib di Mesjid Keraton Yogyakarta. Bahkan KH. Ahmad Dahlan masih mempunyai hubungan kekerabatan dengan pondok pesantren krapyak yogyakarta. ${ }^{34}$

Muhammadiyah sejak awal menyatakan diri sebagai organisasi sosial keagamaan yang bergerak di bidang pendidikan. Pilihan gerakan ini menjadikkan Muhammadiyah sering terlibat dlalam pertarungan wacana keagamaan, khususnya berkaitan dengan relasi agama dan budaya di Indonesia. Muhamadiyah menentang upacara-upacara tertentu, seperti tahlilan, selametan, ziarah kubur, dan bentuk-bentuk ritual lain yang dinilai dapat mencemari otentisitas Islam. Pada saat itu sangat populer istilah gerakan pemusnahan TBC (tabayul-bid'ah-churafat). Muhamadiyah menilai elemen-elemen magis ini nonrasional karena itu praktik Islam harus disterilkan. Maka muhamadiyah mendorong terjadinya proses eksklusi unsur-unsur magis dari Islam kemudian mendasarkan diri pada kalkulasi rasional.untuk memperkuat landasan gerakannya melawan elemen-elemen magis yang dinilai dapat merusak Islam, Muhamadiyah menggulirkan wacana "kembali ke al Quran dan Sunnah".

Tema-tema perdebatan lain yang tidak kalah beratnya adalah masalah ijtihad dan tasawuf. ${ }^{35}$ Muhammadiyah berpendapat bahwa ijihad merupaka instrumen penting bagi kelangsungan dinamika kehidupan masyarakat Islam. Ijtihad akan mampu membawa umat Islam memasuki kehidupan umat Islam yang lebih maju dan nodern. Konsekuensinya, Muhammadiyah menentang konsep taqlid yang dianggapnya sumber konservatisme dan stagnasi dalam Islam. Sedangkan pandangan Muhammadiyah tentang tasawuf adalah kritik atasnya yang cenderung menafikan capaian-capaian materi. Bagi Muhamadiyah tasawuf perlu dimodernisasi sehingga pelakunya tanpa harus melarikan diri dari kehidupan duniawi. Konsepsi mendasar tentang ijtihad ini kemudian mempopulerkan Muhammadiyah sebagai

33 Andre Feillard, NU vis a vis Negara, hal. 5-6

34 KH. Ahmad Dahlan termasuk keturunan yang keduabelas dari Maulana Malik Ibrahim, salah seorang wali songo yang sangat dihormati di kalangan muslim Tradisional. Di samping itu KH. Ahmad Dahlan juga pernah menikahi Nyai Rum, adik Kyai Munawwir Krapyak, salah seorang tokoh NU yang disegani.

35 Alwi Shihab, Islam Sufistik, hal. 251. 
kelompok tajdid (pembaharu) yang berusaha menghidupkan kembali akal pikiran umat Islam, serta membangun kemampuan profesional bagi umat Islam untuk meraih kebahagiaan jasmani dan rohani. ${ }^{36}$ Konsep tajdid dalam terminologi Muhammadiyah merupakan sebuah kanopi konseptual yang mampu merangkul kemajemukan nalar Islam yang memiliki komitmen reformistik-emansipatoris. Salah satu implementasi dari semangat tajdid di Muhamadiyah adalah eksistensi majelis tarjih. Sejumlah rumusan pemikiran Muhamadiyah yang terangkul dalam hasil putusan tarjih menunjukkan kehendak Muhammadiyah untuk membicarakan soal kebenaran. Dalam tradisi Muhammadiyah, keputusan tarjih dimungkinkan untuk diletakkan sebagai rujukan alternatif yang bersifat tentatif bagi pemahaman dan pengalaman keberagamaan warganya, jadi bukan rumusan final atau kebenaran satu-satunya yang harus diikuti. Namun idealisasi tajdid ala Muhammadiyah di era belakangan ini banyak yang mempertanyakan kembali. Mereka menilai Muhammadiyah kehilangan ruh tajdidnya, bahkan mengalami stagnasi pemikiran. ${ }^{37}$

Dinamika muslim kota juga melahirkan al-Irsyad al-Islamiyah pada tanggal 16 september 1914. Tokoh sentral al-Irsyad al-Islamiyah adalah Ahmad Soorkatty. ${ }^{38}$ Isu yang digulirkan al-Irsyad tidak jauh beda dengan Muhammadiyah karena memang kelahiran alIrsyad tidak lepas dari semangat kedua tokoh gerakan tersebut dalam mengembangkan pembaruan Islam di Indonesia. ${ }^{39}$ Corak pemikirannya dapat ditelusuri dari mabadi' al-Irsyad yang meliputi, pertama, memahami ajaran Islam dari al-Qur'an dan Sunnah yang bertakhkim kepada keduanya. Kedua, beriman dengan akidah Islam yang berdasarkan nash-nash al-Qur'an dan Sunnah yang sahih, terutama bertauhid kepada Allah dengan membersihkan unsur-unsur syirik, takhayul, dan churafat. Ketiga, beribadah menurut tuntunan al-Quran dan Sunnah dengan membersihkan dari unsur-unsur bid'ah. Keempat, berakhlak dengan etika susila yang luhur, moral dan etik Islam, serta menjauhi adat istiadat, moral dan etika yang bertentangan dengan Islam. Kelima, memeperdalam dan memperluas ilmu pengetahuan untuk kesejahteraan duniawi dan ukhrawi yang diridhai Allah. Keenam, meningkatkan kehidupan dan penghidupan duniawi dan pribadi masyarakat selama tidak diharamkan oleh Islamdengan nash, serta mengambil kegunaan dari segala alat dan cara teknis, organisasi dan administrasi modern yang bermanfaat bagi pribadi dan umat, materiil dan spirituil. Ketujuh, bergerak dan berjuang secara terampil dan dinamis dengan pengorganisasian dan koordinasi yang baik bersama organisasi lain dengan cara ukhuwah islamiyah dan setia kawan, serta saling membantu dalam memperjuangkan cita-cita Islam yang meliputi kebenaran, kemerdekaan, keadilan, dan kekbajikan, serta keutamaan menuju keridhaan Allah.

36 Abdul Munir Mulkhan, Pemikiran KH. Ahmad Dahlan dan Muhammadiyah dalam Perspektif Perubahan Sosial (Jakarta: Bumi Aksara, 1990), hal. 43.

37 M. Karim Rusli, Muhammadiyah dalam Kritik dan Komentar (Jakarta: Rajawali Press, 1986), hal. 34.

38 Nama lengkapnya adalah Ahmad bin Muhammad bin Muhammad bin Muhammad As-Soorkatty, dilahirkan di desa Udhfu atau Arqu, Dunggulah, Sudan, pada 1874 M. Ia sudah menghafal al Quran pada usia muda di bawah didikan ayahnya sendiri yang juga ulama terkenal. Setelah ayahnya wafat, Soorkaty melanjutkan studi ke Universitas Al Azhar Mesir, lalu belajar ke Mekkah. Ia meraih gelar al Allamah ketika berhasil menyelesaikan tesisnya tentang kajian alQaha wal-Qadhar pada 1908 M. www.alirsyad.co.id

39 Dua tahun menjelang kelahiran al-Irsyad, dalam perjalanannya ke Solo. Ahmad Soorkaty bertemu KH. Ahmad Dahlan. Keduanya terlibat diskusi tentang keislaman yang kemudian mempertemukan keduanya dalam pikiran yang sama, yaitu perlunya pemurnian akidah. Keduanya kemudian berkesimpulan perlunya mengembangkan pemikiran Muhammad Abduh di Indonesia. www.alirsyad.co.id 
Satu-satunya organisasi yang secara lugas menyatakan diri berbasis Islam pedesaan adalah Nabdlatul Ulama (NU), lahir di Surabaya pada tanggal 31 Januari 1926. Secara etimologi, Nabdlatul Ulama terdiri dari dua kata, nahdlah artinya kebangkitan dan ulama artinya kelompok agamawan. Gerakan NU bermula dari upaya advokasi pemikiran kegamaan yang digagas oleh para Kiai pesantren pedesaan. NU dideklarasikan oleh lima belas Kiai di rumah KH. Wahab Chasbullah, di daerah Kertopaten Surabaya. Tokoh sentral NU saat itu adalah KH. Hasyim Asyari dari Pondok Pesantren Tebu Ireng Jombang, ${ }^{40}$ seorang ulama yang terkenal penguasaannya di bidang Tafsir dan Hadits. Kemampuannya di bidang tafsir dan hadits memeudahkan KH. Hasyim Asyari untuk mmengawal proses akulturasi budaya dan Islam. Dalam satu kesempatan ia bersikap keras terhadap tradisi tertentu, namun di kesempatan lain ia menunjukkan sikap akomodatif. Namun secara makro, pemikirannya mewakili kelompok muslim pesantren yang bersebrangan dengan kelompok Islam modernis. Untuk mempertegas pandangan-pandangannya terhadap isu-isu keislaman yang aktual pada masa itu, ia menuangkannya dalam sebuah tulisan, Risalah Ablussunnab wal Jamaah, fi Hadits al-Mawta wa Asyratisa'ah wa Bayani Mafhum al-Sunnah wal-Bid'ah. Dalam tulisannya, KH. Hasyim Asy'ari beragumentasi tentang tradisi masyarakat pedesaan, seperti ritual ke kuburan dalam perspekktif ajaran Islam. Persoalan fundamental lainnya yang juga ia soroti adalah perbedaan substansial antara ablussunnah wal jamaah dan ablul bid'ah.

Isu utama yang diusung pertama kali oleh NU pasca kelahirannya adalah memperjuangkan kebebasan bermadzhab di tanah Mekkah dan Madinah yang saat itu di bawah kekuasaan Raja Su'ud yang mengusung paham Wahabi. Keberanian NU memilih isu perlawanan terhadap doktrin Wahabi cukup strategis. Isu ini secara politis mempercepat popularitas NU di tingkat nasional sekaligus sosialisasi di dunia internasional. Utuk itu NU merasa perlu untuk mengirim delegasi ke Kongres Islam Dunia di Mekkah dengan harapan mendapatkan kesempatan memberikan penjelasan yang komperhensif kepada Raja Su'ud tentang pentingnya sikap toleransi, saling menghormati dan mengakui realitas perbedaan pendapat di kalangan umat Islam. ${ }^{41} \mathrm{NU}$ pun berdiskusi merumuskan pola beragama Islam dalam konteks kehidupan masyarakat yang dikelilingi tradisi. NU lalu mengkaji soal musik, olahraga, seni tari dan mode pakaian. ${ }^{42}$ Kajian NU yang cukup fenomenal adalah tentang mode pakaian yang ternyata mendapat responluas masyarakat, termasuk kolonial Belanda. Bahkan Ahmad Syalabi(1977), sejarawan Mesir, mempercayai kajian ini tidak hanya berlatarbelakang budaya tapi juga politik perlawanan kultural terhadap kolonial Belanda. KH. Hasyim Asyari secara khusus juga memberikan landasan keberagamaan masyarakat ketika sambutan pembukaannya (iftitah) dalam Muktamar NU III memberikan inspirasi para Kiai untuk membentuk Lajnah Nasibin, yaitu badan ad hoc beranggotakan 9 Kiai yang bertugas menyosialisasikan paham Ablussunnah waljamaah. ${ }^{43}$

40 KH. Hasyim Asy’ari adalah putra Kiai Jawa dan Ibunya masih keturunan bangsawan Jawa, Jaka Tingkir. Ia pernah belajar kepada Syaikh Hmad Khatib Minangkabau, Kiai Nawawi Banten, Kiai Kholil Bangkalan dan Kiai Mahfudz Termas. Lihat Lathiful Khuluq, Fajar Kebangkitan Ulam, Biografi KH. Hasim Asy'ari (Yogyakarta: LKiS, 2000), hal. 26.

41 Muchit Muzadi, Mengenal Nahdlatul Ulama (Jember: Mesjid Sunan Kalijaga, 2004), hal. 6,7.

42 Aziz Masyhuri, Masalah Keagamaan: Hasil Muktamar dan Munas Ulama NU (surabaya: RMI, 1997), hal. 14

43 Teks sambutan iftitah KH. Hasyim Asy'ari tersebut kemudian dikenal sebagai Qanun Asasi Nahdlatul Ulama. Lihat Hilmi Muhammadiyah dan Sulthan Fatoni, NU Identitas Islam Indonesia (Jakarta: Elsas, 2004), hal. 126 
Mensermati corak pemikiran NU di atas tampak bahwa NU sangat apresiatif terhadap tradisi sehingga komunitas Kiai dalam tubuh NU dikenal sebagai para agamawan yang mampu menerima, melestarikan dan meneruskan tradisi dan budaya generasi sebelumnya serta mampu melakukan eksplorasi, kreasi dan inovasi yang lebih baik dan bermanfaat. NU mempunyai kesadaran historis dan kemampuan mereformasi kondisi secara kultural maupun pemikiran kurang relevan. ${ }^{44}$ Dalam budaya NU, masa lau dihormati dan simbol dihargai karena berisi dan bertanggung jawab atas pengalaman berbagi generasi. Tradisi adalah cara untuk mengintegrasikan monitoring tindakan secara reflektif dengan penataan ruang waktu dalam komunitas. Ini adalah sarana untuk menangani ruang dan waktu, yang memasukkan segala aktivitas atau pengalaman tertentu di dalam keberlanjutan masa lau, masa kini dan masa depan yang pada gilirannya terstruktur oleh praktik-praktik sosial yang telah berlangsung. ${ }^{45}$

Berarti terdapat dua sisi yang menjadi concern NU, yitu pelestarian tradisi masa lalu yang masih relevan dan baik sekaligus upaya eksplorasi atas sesuatu yang lebih baik. Dua sisi garapan NU di atas berlangsung secara natural. Sehingga dalam setiap waktu proses pengukuhan tradisi berjalan seiring dengan proses kreasi dan inovasi. Bahkan tidak jarang keduanya terjadi secara bersamaan, dalam kasus yang sama, dan dengan tokoh yang berbeda. Misalnya Masdar Farid Masudi, pernah melontarkan pemikiran inovatif bahwa ritual haji tidak hanya bisa dilakukan pada bulan Dzulhijjah. Menurutnya, Al Quran sudah menegaskan, $A l$ Hajju Asyhurun Ma'lumat, maksudnya musim haji itu membentang dari bulan syawal hingga dzulhijjah. Ia melengkapi argumentasinya dengan pendekatan sosiologi, di antaranya problem kemanusiaan sebagai akibat kuantits umat Islam yang semakin besar. Di sisi lain secara bersamaan terjadi proses pengukuhan pemikiran konservatif dengan menolak pendapat Masdar. Adalah KH. Sahal Mahfudz yang kukuh menolak argumentasi Masdar dengan berpendapat bahwa ritual haji sangat terkait dengan teks Rasulullah, "al bajj 'arafah", maksudnya subsrtansi ritual haji adalah wukuf di arafah, sedangkan wukuf di Arafah hanya terjadi pada tanggal 10 Dzulhijjah. Maka ritual haji yang dilakukan tanpa melaksanakan wukuf di Arafah adalah sia-sia (tidak sah). Hal menarik lainnya adalah proses perdebatan antara Said Aqil Siradj dan Ulil Abshar Abdalla seputar metodologi pemikiran Islam. Aqil Siradj berpendapat bahwa karakter dasar NU yang berhaluan ahlussunnah wal jamaah adalah penghargaannya atas tradisi. Konsekuensinya, proses inovasi keagamaan apapun tetap diletakkan di atas landasan pemikiran ulama klasik. Tradisi bagi NU tidak sepenuhnya statis karena ia harus ditemukan ulang oleh setiap generasi baru ketika ia mengmbil alih warisan budaya pendahulunya. Tradisi tidak selalu melawan perubahan ketika terjadi konteks di mana ada beberapa pertanda temporal dan spasial yang terpisah dengan catatan perubahan itu bisa memiliki bentuk yang bermakna. ${ }^{46}$ Jadi Istilah 'pembaruan' di internal NU dapat dipahami sebagai proses aktualisasi pemikiran ulama klasik sekaligus proses kreasi dan inovasi keagamaan sebagai respons perkembangan kehidupan sehari-hari. Sikap ini berlandaskan pada spirit jalan tengah (al-wasathiyah) yang berlaku di semua aspek kehidupan, termasuk pemikiran Islam. Al wasathiyah dipercayai mempunyai kapasitas untuk memproduksi pemikiran baru. Yusuf Qardhawi menyatakan bahwa al wasathiyah merupakan paradigma berkarakter yang menggabungkan antara orisinalitas dan kontempralitas, keseimbangan antara aspek-aspek statis

\footnotetext{
44 Abdurrahman Badawi, al Insan al kamil fi al Islam (Kuwait: Wukalat al Mathbuah, 1976), hal. 12.

45 Anthony Giddens, The Consequences of Modernity, diterjemah oleh Nurhadi dengan judul , Konsekuensi-Konsekuensi Modernitas (Yogyakarta: Kreasi Wacana, 2005), hal. 49.

46 Anthony Giddens, The Consequences of Modernity, hal.49
} 
dan menerima perubahan dalam ajaran Islam, bersikap moderat (tidak ekstrem), tidak melakukan pendekatan parsial dalam memahami Islam dan bersikap memudahkan sepanjang tidak berdosa. Al wasathiyah juga merupakan paradigma berpegang teguh pada prinsip relativitas dan karena itu membuka ruang yang luas bagi perbedaan. Dalam filsafat ilmu paradigma ini berpegang pada kausalitas yang longgar dalam bingkai keimanan. ${ }^{47}$

\section{PENUTUP}

Perubahan sosial dan agama menemukan relevansinya ketika sejarah manusia secara faktual tidak pernah lepas dari sisi kehidupan keagamaannya. Masyarakat Barat pernah merasa terpuruk dalam sistem pemerintahan kependetaan pada zaman pertengahan. Saat itu mereka menganggap kekuasaan keagamaan telah mengakibatkan penderitaan masyarakat. Sehingga dogma-dogma keagamaan tidak lagi untuk ditaati bahkan sebaliknya justru untuk dilawan sebagai reaksi atas penindasan sekaligus atas nama pengembalian harga diri kemanusiaan. Barat untuk selanjutnya mampu menapaki perubahan yang mencapai puncaknya di era pencerahan (Enlighment) yang bercirikan masyarakat Barat yang bebas, sekuler, individual, dan rasional.

Agama sebagai suatu realitas sosial dilihat dalam beberapa perspektif, pertama, secara epistimologi agama dapat dikaji dari masyarakat agama untuk menghasilkan keteranganketerangan ilmiah dan pasti demi kepentingan masyarakat agama itu sendiri dan masyarakat luas pada umumnya. Kedua, obyek material, yaitu kelompok yang menjadikan agama atau nilai-nilai agama sebagai unsur konstitutif utama. Ketiga, obyeknya formal, yaitu mengkaji agama dari sudut empiris sosiologis: seberapa jauh agama dan nilai-nilai keagamaan memainkan peranan dan berpengaruh atas eksistensi dan operasi masyarakat manusia. Seberapa jauh unsur kepercayaan mempengaruhi terbentuknya kepribadian pemeluknya, ikut ambil bagian dalam menciptakan jenis-jenis budaya, mewarnai terbentuknya komunitas, strata sosial, organisasi dan institusi sosial. Bagaimana agama mempengaruhi proses sosial, perubahan sosial, sekularisasi, fanatisme, konflik dan sebagainya. Keempat, dari sisi fungsi agama yang memberikan dasar-dasar pemikiran obyektif, ilmiah dan rasional mengenai fenomena yang terjadi di kalangan masyarakat. Sehingga dapat dibedakan antara dogma sebagai sesuatu yang bersifat sakral, mutlak, abstrak, ideologis statis dan supra empirik, dengan perilaku sosial masyarakat agama yang profan, nisbi, konkret, dan dinamis.

\section{REFERENSI}

Abdullah Taufik. 1982. Tesis Weber dan Islam di Indonesia. Jakarta: LP3ES.

Anderson, Stephen K. 1993. Sosiolgi Makro-Sebuah Pendekatan terbadap Realitas Sosial, penerjemah Farid Wajdi dan S. Menno. Jakarta: Rajawali.

Badawi, Abdurrahman. 1976.al Insan al kamil fi al Islam. Kuwait: Wukalat al Mathbuah.

Benda, Harry J. 1985. The Crescent and the Rising Sun. The Hague.

Bendix, Reinhard, 1962. Max Weber: An Intellectual Potrait. New York: Double Day, Anchor Book.

Berg, H.J. Van Den. 2003. Asia dan Dunia Sejak 1500. dikutip Simuh, Islam dan Pergumulan Budaya Jawa. Jakarta: Teraju.

47 M. Yunus, dkk, Ahlussunnah wal Jamaah NU: Konseptualisasi Tradisi yang Hidup (Mesir: SAS Center, 2004), hal. 88. 
Daud, Wan Mohd Nor Wan. 1998. Filsafat dan Praktik Pendidkan Islam. Bandung: Mizan.

Fealy, Greg. 2003. Ijtihad Politik Ulama. Yogyakarta: LKiS.

Feillard, Andre. 1999. NU vis a vis Negara. Yogyakarta: LKiS.

Giddens, Anthony. 2005. The Consequences of Modernity, diterjemah oleh Nurhadi dengan judul, Konsekuensi-Konsekuensi Modernitas. Yogyakarta: Kreasi Wacana.

Hadi, Edy Kunan. 2003. Syaikh Ahmad Khatib Sambas. The Ford Foundation.

Hefner, Robert W. dalam bukunya yang diedit oleh Mun'im Sirry, 2002. Islam Liberalisme Demokrasi. Jakarta: Paramadina.

Lukens-Bull, Ronald Alan. 2004. Peacefull Jihad diterjemahkan oleh Abdurrahman Mas'ud dkk dengan Judul Jihad ala Pesantren di Mata Antropolog Amerika. Yogyakarta: Gama Media.

Masyhuri, Aziz. 1997. Masalah Keagamaan: Hasil Muktamar dan Munas Ulama NU. Surabaya: RMI.

Mughni, Djuretna A. Imam. 1994. Moral dan Religi Menurut Emile Durkheim dan Henri Bergson. Yogyakarta: Kanisius.

Mulkhan, Abdul Munir. 1990. Pemikiran KH. Abmad Dablan dan Mubammadiyah dalam Perspektif Perubahan Sosial. Jakarta: Bumi Aksara.

Muzadi, Muchit. 2004. Mengenal Nabdlatul Ulama. Jember: Mesjid Sunan Kalijaga.

Noer, Deliar. 1996. Gerakan Modern Islam di Indonesia 1900-1942. Jakarta: LP3ES.

Reid, Anthony. 2003. Kekacauan dan Kerusuban. Leiden-Jakarta: INIS.

Rusli, M. Karim. 1986. Mubammadiyah dalam Kritik dan Komentar. Jakarta: Rajawali Press.

Scharf, Betty R. 2004. Sosiologi Agama, terjemah oleh Machnun Husein. Jakarta: Prenada Media.

Shihab, Alwi. 2001. Islam Sufistik. Bandung: Mizan.

Simuh. 2003. Islam dan Pergumulan Budaya Jawa. Jakarta: Teraju.

Soekanto, Soerjono. 1974. Sosiologi Suatu Pengantar. Jakarta: Yayasan Penerbit UI.

Sofwan, Ridin dkk. 2004. Islamisasi di Jawa. Yogyakarta: Pustaka Pelajar.

Suminto, Aqib. 1985. Politik Islam Hindia Belanda. Jakarta: LP3ES.

Weber, Max. 1958. The Protestan Ethic and the Spirit of Capitalism, diterjemabkan oleh Talcott Parsons. New York: Charles Scribner's Son.

Yunus, M. 2004. dkk. Ablussunnah wal Jamaah NU: Konseptualisasi Tradisi yang Hidup. Mesir: SAS Center.

www.alirsyad.co.id 